\title{
MODEL PREDIKSI FAKTOR KEJADIAN HIPERLIPIDEMIA PESERTA ASKES DI KECAMATAN METRO TIMUR KOTA METRO
}

\author{
PREDICTION MODEL FACTORS OF HYPERLIPIDEMIA EVENTS IN \\ PARTICIPANTS ASKES IN EAST METRO DISTRICT \\ METRO CITY
}

\author{
Supardi \\ Akademi Keperawatan Dharma Wacana Metro
}

\begin{abstract}
ABSTRAK
Fenomena pada abad ke-20, penyakit serangan jantung dan pembuluh darah telah menggantikan peran penyakit tuberculosis di Indonesia. Penyakit serangan jantung adalah suatu penyakit yang menyebabkan kematian. Hiperlipidemia adalah sebuah masalah kesehatan masyarakat karena berhubungan terhadap tingginya presentase sebuah penyakit dengan kematian koroner dan mengurangi produktivitas. Faktor-faktor penyebab hiperlipidemia adalah umur, jenis kelamin, latar belakang pendidikan, indeks masa tubuh, aktivitas olahraga, penyakit keturunan, dan pola makan. Objek penelitian ini adalah untuk mengetahui factor-faktor hiperlipidemia yang terjadi pada para peserta Askes di Kecamatan Metro Timur. Metode dari penelitian ini adalah metode kuantitatif dengan menggunakan rancangan cross sectional, dengan sampel sebanyak 137 responden. Tidak ada hubungan antara umur dengan hiperlipidemia (p:0,509), tidak ada hubungan antara jenis kelamin dengan hiperlipidemia (p:0,973), tidak ada hubungan antara latar belakang dengan hiperlipidemia (p:0,299), Terdapat hubungan antara aktivitas olahraga hiperlipidemia (p:0,048), terdapat hubungan antara latar belakang penyakit keturunan dengan hiperlipidemia ( $\mathrm{p}: 0,000)$, terdapat hubungan antara indeks masa tubuh dengan hiperlipidemia (p:0,011), terdapat hubungan antara pola makan/kebiasaan makan dengan hiperlipidemia (p:0,002). Seseorang yang memiliki resiko hiperlipidemia, mereka harus melakukan pemeriksaan kesehatan darahnya secara berkala, agar kolesterol dalam darah dapat di konrol.
\end{abstract}

Keyword : hiperlipidemia, Pola hidup sehat, olahraga secara teratur.

\begin{abstract}
The $20^{\text {th }}$ century phenomenon, heart attack and vein have replaced role of disease of tuberculosis in Indonesia, heart attack is one of deseases whict causes death. Hiperlipidemia is a problem of public health because it relates to high presence of an illness and mortality of coronary and reducing of produktifity. The factors of hiperlipidemia are : age, gender, beckground of study, the indek a pertod of body, sport activity, beckground of heredity disease and custom how to eat. the object of this research is to find out some factors hiperlipidemia as reflected in Kecamatan Metro Timur, Metro. The method of this research is quantitative method because it refers to concern with Cross Sectional model that oecurs to 137 respondents. There is no relation between age and hiperlipidemia $(p=0,509)$, there is no relation between gender and hiperlipidemia $(\mathrm{p}=0,973)$, there is no relation between background of study and hiperlipidemia $(p=0,299)$, there is relation between sport activity and hiperlipidemia $(p=0,048)$, there is relation between background of heredity disease and hiperlipidemia $(p=0,000)$, there is relation between the indek a pertod of body and hiperlipidemia $(\mathrm{p}=0,011)$, tere is relation between the custom how to eat and hiperlipidemia $(\mathrm{p}=0,002)$. Same one who has got some risk of hiperlipidemia they must have to get blood medical check up routinely periodically, the doctor can control the cholesterol in their blood.
\end{abstract}

Keyword : hiperlipidemia, Healthy habit, exercise routinly, 


\section{PENDAHULUAN}

Kemajuan perekonomian sebagai dampak dari pembangunan di negara-negara sedang berkembang sebagai-mana di Indonesia menyebabkan perbaikan tingkat hidup. Hal ini menjadikan kesehatan masyarakat meningkat, di samping itu terjadi pula perubahan pola hidup. Perubahan pola hidup ini yang menyebabkan pola penyakit berubah, dari penyakit infeksi dan rawan gizi ke penyakit-penyakit degeneratif, diantaranya adalah penyakit jantung dan pembuluh darah (Kardiovaskuler) dan akibat kematian yang ditimbulkannya. Hasil survei kesehatan nasional pada tahun 2001 menunjukkan bahwa $26,3 \%$ penyebab kematian adalah penyakit jantung dan pembuluh darah, kemudian diikuti oleh penyakit infeksi, pernapasan, pencernaan, neoplasma dan kecelakaan lalu lintas ${ }^{11}$.

Menyadari terjadinya perubahan pola penyakit dari penyakit infeksi ke penyakit degeneratif serta endemisitas penyakit jantung dan pembuluh darah yang terjadi dinegara-negara maju, Pemerintah Republik Indonesia perlu menyusun kebijakan penyelenggaraan dan strategi baru pembangunan kesehatan. Kebijakan dan strategi baru tersebut telah disusun dalam suatu system yang disebut Gerakan Pembangunan Berwawasan Kesehatan sebagai Strategi Nasional menuju Indonesia Sehat $2010^{4}$.

Di Indonesia, penyakit jantung juga cenderung meningkat sebagai penyebab kematian. Data kesehatan rumah tangga (SKRT) tahun 1996 menunjukan bahwa proporsi penyakit ini meningkat dari tahun ke tahun sebagai penyebab kematian. Tahun 1975 kematian akibat penyakit jantung hanya 5,9\%, tahun 1981 meningkat, menjadi 9,1 $\%$, tahun 1986 melonjak menjadi $16 \%$ dan tahun 1995 meningkat menjadi $19 \%$. Sensus nasional tahun 2001 menunjukkan bahwa kematian karena kardiovaskuler termasuk penyakit jantung koroner adalah sebesar 26,4 $\%^{5}$ dan sampai dengan saat ini PJK juga merupakan penyebab utama kematian dini pada sekitar $40 \%$ dari sebab kematian lakilaki usia menengah ${ }^{1}$.

Kondisi Penyakit kardiovaskuler di Propinsi Lampung tercatat secara berurutan dari tahun 2007 sampai dengan tahun 2009 adalah 4719 orang, 6964 orang dan 4736, 
dari kasus tersebut tercatat 47 orang meninggal pada tahun 2007 dan 82 meninggal pada tahun 2008 serta 47 orang meninggal pada tahun 2009. ${ }^{4}$

Selanjutnya laporan Dinas Kesehatan Kota Metro bahwa penyakit kardiovaskuler pada tahun 2007 tercatat 617 orang dan tahun 2008 tercatat 1189 serta pada tahun 2009 tercatat 392 orang.

Hasil program pemeriksaan darah bagi peserta Askes yang dilakukan di Kota Metro pada tahun 2009 diketahui bahwa kejadian hiperlipidemia sebanyak 18,5\%, dan terdistribusi di Kecamatan Metro Utara 15,8\%, di Kecamatan Metro Pusat 20,4\%, di Kecamatan Timur 22,4\%, di Kecamatan Metro Barat 17,4 \%, dan di Kecamatan Metro Selatan 13,8\%.

Kadar kolesterol darah yang tinggi dapat mengendap pada dinding pembuluh darah bagian dalam, dan selanjutnya akan menghambat aliran darah dan oksigen sehingga mengganggu metabolisme sel otot jantung. Mengkonsumsi makanan tinggi kolesterol dan lemak jenuh menyebabkan peningkatan kolesterol intrasel, dan akan disimpan sebagai ester kolesterol yang menyebabkan penurunan transkripsi gen reseptor High Density-Lipoprotein (HDL) dan menurunkan sintesis LDL. Hal ini menyebabkan kadar LDL-kolesterol di dalam sirkulasi akan semakin meningkat ${ }^{9}$.

Hiperlipidemia merupakan salah satu faktor resiko penyebab penyakit jantung koroner di samping faktor-faktor lain seperti hipertensi, merokok, riwayat keluarga, obesitas, stress, gaya hidup, jenis kelamin dan diabetes militus. Hiperlipidemia adalah suatu keadaan yang menunjukkan adanya peningkatan lemak darah termasuk kolesterol dan trigliserida atau peningkatan dari lipoprotein-lipoprotein khusus ${ }^{3}$.

\section{METODE}

Jenis penelitian ini adalah penelitian kuantitatif. Menggunakan rancangan Cross Sectional. Populasi dalam penelitian adalah seluruh peserta Askes di Kecamatan Metro Timur baik laki-laki maupun perempuan yang mengikuti general check up. Pengambilan sampel dalam penelitian ini adalah dengan kriteria sebagai berikut : Peserta Askes Kecamatan Metro Timur, lakilaki maupun perempuan. Mengikuti general check up yang dilaksanakan di Rumah Sakit Mardi Waluyo Kota Metro pada tahun 2010. Penelitian dilakukan pada bulan oktober 2010 dengan sampel sebanyak 137 orang.

Variable dependen dalam penelitian ini adalah: Hiperlipidemia (Kolesterol Total 
dan Trigliserida), Variabel independen dalam penelitian ini adalah: Usia, Jenis kelamin, Jenjang pendidikan, IMT, Olahraga, Riwayat penyakit keturunan, Kebiasaan makan. Pengambilan data kimia darah diambil di RS Mardiwaluyo Kota Metro, selanjutnya untuk melengkapi data yang diperlukan diberikan kuisioner kepada ibu-bapak dengan cara didatangi ke rumah masing-masing. Selanjutnya dianalisis dengan menggunakan Chi Square untuk mengetahui hubungan variabel dependen dengan variabel in dependen.

\section{HASIL DAN PEMBAHASAN}

\section{Karakteristik responden}

Rerata umur responden adalah 49,99 tahun. Dari tabel 1 terlihat bahwa jumlah responden dengan umur $\leq 40$ tahun sebanyak 12 orang $(8,75 \%)$, responden dengan umur 41-45 tahun sebanyak 10 orang (7,30\%), responden dengan kelompok umur 46-50 tahun sebanyak 48 orang $(35,05 \%)$, responden dengan kelompok umur 51-55 tahun sebanyak 39 orang $(28,46 \%)$, dan responden dengan kelompok umur 56 tahun keatas sebanyak 28 orang $(20,44 \%)$.
Tabel 1

Disbtribusi responden menurut umur, jenis kelamin, jenjang pendidikan, aktifitas olahraga, IMT, riwayat keturunan, hiperlipidemia, LDL, HDL, trigliserida, kolesterol

\begin{tabular}{|c|c|c|}
\hline Variabel & $\begin{array}{l}\text { Jumlah } \\
\text { (orang) }\end{array}$ & $\begin{array}{c}\text { Persen } \\
(\%)\end{array}$ \\
\hline \multicolumn{3}{|l|}{ Kelompok umur } \\
\hline$\leq 40$ tahun & 12 & 8,75 \\
\hline$\overline{4} 1-45$ tahun & 10 & 7,30 \\
\hline 46-50 tahun & 48 & 35,05 \\
\hline 51-55 tahun & 39 & 28,46 \\
\hline$\geq 56$ tahun & 28 & 20,44 \\
\hline Jumlah & 137 & 100 \\
\hline \multicolumn{3}{|l|}{ Jenis kelamin } \\
\hline Laki-laki & 19 & 13,9 \\
\hline Perempuan & 118 & 86,1 \\
\hline Jumlah & 137 & 100 \\
\hline \multicolumn{3}{|l|}{ Jenjang pendidikan } \\
\hline SLTA & 34 & 24,8 \\
\hline Diploma II & 49 & 35,8 \\
\hline Strata I & 54 & 39,4 \\
\hline Jumlah & 137 & 100 \\
\hline \multicolumn{3}{|l|}{ Aktifitas olah raga } \\
\hline Tidak berolahraga & 78 & 56,9 \\
\hline Berolahraga & 59 & 43,1 \\
\hline Jumlah & 137 & 100 \\
\hline \multicolumn{3}{|l|}{ Indek Masa Tubuh } \\
\hline Berlebih & 78 & 56,9 \\
\hline Normal/ideal & 59 & 43,1 \\
\hline Jumlah & 137 & 100 \\
\hline \multicolumn{3}{|l|}{ Riwayat penyakit keturunan } \\
\hline Ada riwayat penyakit Keturunan & 51 & 37,2 \\
\hline Tidak ada riwayat penyakit & 86 & 62,8 \\
\hline \multicolumn{3}{|l|}{ Keturunan } \\
\hline Jumlah & 137 & 100 \\
\hline \multicolumn{3}{|l|}{ Kebiasaan makan } \\
\hline Tinggi lemak & 56 & 59,1 \\
\hline Rendah lemak & 81 & 40,9 \\
\hline Jumlah & 137 & 100 \\
\hline \multicolumn{3}{|l|}{ Hiperlipidemia } \\
\hline Hiperlipid & 68 & 49,6 \\
\hline Tidak hiperlipid & 69 & 50,4 \\
\hline Jumlah & 137 & 100 \\
\hline \multicolumn{3}{|l|}{ Kolesterol total } \\
\hline Tinggi & 23 & 16,8 \\
\hline Rendah/normal & 114 & 83,2 \\
\hline Jumlah & 137 & 100 \\
\hline \multicolumn{3}{|l|}{ Trigliserida } \\
\hline Tinggi & 58 & 42,3 \\
\hline Rendah/normal & 79 & 57,7 \\
\hline Jumlah & 137 & 100 \\
\hline
\end{tabular}


Dari tabel 1 terlihat bahwa usia responden $\leq 40$ tahun sebanyak 12 orang $(8,75 \%)$, usia 41-45 tahun sebanyak 10 orang (7,3\%), usia 46-50 tahun sebanyak 48 orang $(35,05 \%)$ usia 51-55 tahun sebanyak 39 orang $(28,46 \%)$ dan $\geq 56$ tahun sebanyak 28 orang $(20,44 \%)$. Selanjutnya data usia dikelompokan dalam dua kategorik yaitu tidak beresiko usia $\leq 45$ tahun sebanyak 22 orang $(16,1 \%)$ dan beresiko usia $\geq 46$ tahun sebanyak 115 orang $(83,9 \%)$.

Rerata jenis kelamin adalah perempuan yaitu sebanyak118 orang $(86,1 \%)$ dan lakilaki sebanyak 19 orang $(13,9 \%)$

Dari tabel 1 menunjukkan bahwa pada jenjang pendidilan SLTA sebanyak 34 orang (24,8\%), selanjutnya untuk jenjang pendidikan Diploma II sebanyak 49 orang $(35,8 \%)$, dan jenis pendidikan sarjana strata satu sebanyak 54 orang $(39,4 \%)$

Sesuai dengan tabel 1, bahwa sebanyak 78 orang $(56,9 \%)$ responden tidak melakukan aktifitas olahraga, dan hanya sebanyak $59(43,1 \%)$ responden melakukan aktifitas olahraga.

Rerata Indek Masa Tubuh (IMT) responden menunjukkan angka berlebih yakni sebanyak 78 orang $(56,9 \%)$ memiliki berat badan berlebih, dan yang memiliki berat badan normal sebanyak 59 orang atau sekitar $43,1 \%$.

Rerata responden yang memiliki riwayat penyakit keturunan memiliki hiperkolesterol sebanyak 51 orang $(37,2 \%)$ dan responden sebanyak 86 orang $(62,8 \%)$ tidak memiliki riwayat penyakit keturunan memiliki hiperkolesterol.

Rerata responden yang mengkonsumsi makanan tinggi lemak sebanyak 56 orang $(40,9 \%)$ dan responden yang mengkonsumsi makanan rendah lemah sebanyak 81 orang $(59,1 \%)$

Sesuai dengan tabel 1, bahwa responden yang memiliki hiperlipidemia sebanyak 68 orang $(49,6 \%)$ dan responden yang tidak hiperlipid sebanyak 69 orang $(50,4 \%)$.

Dari tabel 1, juga terlihat responden yang memiliki kolesterol total > $200 \mathrm{mg} / \mathrm{dL}$ sebanyak 23 orang $(16,6 \%)$ dan responden yang memiliki kolesterol total $<200 \mathrm{mg} / \mathrm{dL}$ sebanyak 114 orang $(83,2 \%)$. Selanjutnya responden yang memiliki kadar trigliserida $>150 \mathrm{mg} / \mathrm{dL}$ sebanyak 58 orang $(42,3 \%)$ dan responden yang memiliki kadar trigliserida $\leq 150$ sebanyak 79 orang $(57,7 \%)$. 
Analisis Data

1. Usia responden dan kejadian hiperlipidemia

Tabel 2.

Distribusi responden menurut usia dan terjadinya terjadinya hiperlipidemia.

\begin{tabular}{ccccc}
\hline $\begin{array}{c}\text { Umur } \\
\text { responden }\end{array}$ & $\begin{array}{c}\text { Hiperlipidemia } \\
\text { Tidak } \\
\text { hiperlipid }\end{array}$ & hiperlipid & $\boldsymbol{N}$ & $\begin{array}{l}\text { p- } \\
\text { value }\end{array}$ \\
& $\mathbf{n}$ & $\mathbf{n}$ & & \\
\hline$(\leq 45$ tahun $)$ & 13 & 9 & 22 & 0,509 \\
$(\geq 46$ tahun $)$ & 56 & 59 & 115 & \\
\hline Jumlah & & & 137 & \\
\hline
\end{tabular}

Hasil analisis menggambarkan bahwa usia responden $\leq 45$ tahun sebanyak 22 $(16,1 \%)$ dan responden berusia $>45$ tahun sebanyak 115 (83,9\%). Dari hasil ini terlihat bahwa variabel usia tidak tersebar merata ke dalam dua kategori (usia $\leq 45$ tahun dan berusia $\geq 46$ tahun) dan hampir seluruh responden dalam penelitian ini banyak yang beresiko terhadap hiperlipidemia

Hasil analisis usia responden dengan terjadinya hiperlipidemia diperoleh bahwa ada sebanyak 9 (40,9\%) responden yang berusia $\leq 45$ tahun kejadian hiperlipidemia . Sedangkan responden yang beresiko atau berumur $\geq 46$ tahun sebanyak 59 (51,3\%) yang kejadian hiperlipidemia. Hasil uji statistik diperoleh nilai $\mathrm{p}=0,509$ maka dapat disimpulkan bahwa tidak ada hubungan yang signifikan usia dengan kejadian hiperlipidemia. Dari hasil analisis diperoleh pula nilai $\mathrm{OR}=0,657$, artinya bahwa usia lebih dari 45 tahun bukan merupakan faktor resiko terjadinya hiperlipidemia.

Hasil ini sama dengan hasil penelitian yang dilakukan oleh Sukardi (2010) ${ }^{2}$, yang menemukan frekuensi usia responden banyak berusia lebih dari 45 tahun, dan dari hasil analisis bahwa tidak terdapat hubungan yang signifikan usia dengan kejadian hiperlipidemia

Hasil penelitian ini berbeda dengan yang dilakukan oleh Kamso, Purwantyastuti, Juwita (2002), bahwa lanjut usia tinggal di kota padang mempunyai prevalensi $56,1 \%$ untuk hiperkolesterolemia dan prevalensi LDL tinggi sebanyak $64,6 \%{ }^{12}$

Hasil ini berbeda dengan teori yang disampaikan oleh Barras dalam Muhammad (2009) bahwa biasanya jumlah lemak dalam tubuh cenderung meningkat dengan bertambahnya usia ${ }^{3}$.

Kondisi ini kemungkinan disebabkan oleh responden wanita lebih banyak dibandingkan dengan responden laki-laki. 
2. Jenis kelamin responden dan terjadinya hiperlipidemia

Tabel 3.

Distribusi responden menurut jenis kelamin dan terjadinya hiperlipidemia.

\begin{tabular}{ccccc}
\hline \multirow{2}{*}{$\begin{array}{c}\text { Jenis } \\
\text { kelamin } \\
\text { responden }\end{array}$} & $\begin{array}{c}\text { Hiperlipidemia } \\
\text { Tidak } \\
\text { hiperlipid }\end{array}$ & Hiperlipid & N & p- \\
vaki-laki & 9 & 10 & 19 & 0,973 \\
Perempuan & 60 & 58 & 118 & \\
\hline Jumlah & 69 & 68 & & \\
\hline
\end{tabular}

Hasil analisis menggambarkan bahwa jenis kelamin laki-laki sebanyak 19 (13,9\%) dan jenis kelamin perempuan sebanyak 116 $(86,1 \%)$. Dari hasil ini terlihat bahwa variabel jenis kelamin tidak tersebar merata ke dalam dua kategori dan hampir seluruh responden dalam penelitian ini banyak yang berjenis kelamin perempuan yang tidak beresiko terhadap hiperlipidemia.

Hasil analisis jenis kelamin responden dengan kejadian hiperlipidemia diperoleh bahwa ada sebanyak $10(52,6 \%)$ responden laki-laki dengan kejadian hiperlipidemia. Sedangkan responden yang berjenis kelamin perempuan sebanyak 58 (49,2\%) dengan kejadian hiperlipidemia. Hasil uji statistik diperoleh nilai $\mathrm{p}=0,973$ maka dapat disimpulkan bahwa tidak ada hubungan yang signifikan jenis kelamin dengan kejadian hiperlipidemia. Dari hasil analisis diperoleh pula nilai $\mathrm{OR}=0,870$, artinya bahwa jenis kelamin bukan merupakan faktor resiko terjadinya hiperlipidemia.

Hasil ini sama dengan hasil penelitian yang dilakukan oleh Sukardi (2010), yang menemukan frekuensi responden jenis kelamin perempuan lebih banyak dibandingkan laki-laki, dan dari hasil analisis bahwa tidak terdapat hubungan yang signifikan jenis kelamin dengan kejadian hiperlipidemia ${ }^{2}$.

Hasil ini berbeda dengan pendapat Freeman dan Junge (2008) bahwa jenis kelamin laki-laki sampai umur 50 tahun memiliki resiko 2-3 kali lebih besar dibandingkan perempuan untuk mengalami arteroklorosis oleh kolesterol ${ }^{7}$.

Kondisi ini kemungkinan disebabkan oleh jenis kelamin perempuan lebih banyak dibandingkan leki-laki. Pada wanita usia diatas 50 tahun atau setelah menapous memiliki resiko yang sama dengan laki-laki. Masa premenopouse dilindungi oleh hormone estrogen sehingga dipercaya mencegah terbentuknya arteroklerosis. 


\section{Jenjang pendidikan responden dan terjadinya hiperlipidemia}

Tabel 4.

Distribusi responden menurut jenjang pendidikan dan terjadinya hiperlipidemia.

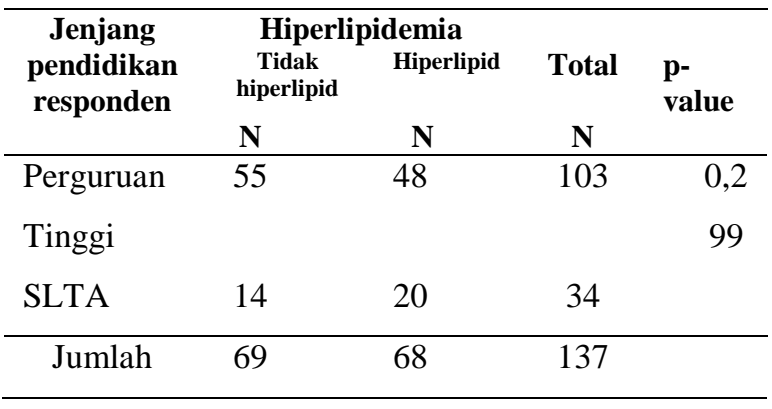

Hasil analisis jenjang pendidikan responden dengan terjadinya hiperlipidemia diperoleh bahwa ada sebanyak $48(46,6 \%)$ responden jenjang pendidikan perguruan tinggi dengan kejadian hiperlipidemia. Sedangkan responden yang berjenjang pendidikan SLTA sebanyak $20 \quad(58,8 \%)$ dengan kejadian hiperlipidemia. Hasil uji statistik diperoleh nilai $\mathrm{p}=0,299$ maka dapat disimpulkan bahwa tidak ada hubungan yang signifikan jenjang pendidikan dengan kejadian hiperlipidemia. Dari hasil analisis diperoleh pula nilai $\mathrm{OR}=1,637$, artinya bahwa jenjang pendidikan SLTA mempunyai resiko 1,637 kali untuk terjadinya hiperlipidemia dibanding jenjang pendidikan tinggi.

\section{Aktifitas olah raga dan terjadinya hiperlipidemia}

Tabel 5.

Distribusi responden menurut aktifitas olahraga dan terjadinya hiperlipidemia.

\begin{tabular}{lllll}
\hline $\begin{array}{c}\text { Aktifitas olah } \\
\text { raga responden }\end{array}$ & $\begin{array}{c}\text { Hiperlipidemia } \\
\text { Tidak } \\
\text { hiperlipid } \\
\text { N }\end{array}$ & $\begin{array}{l}\text { Hiper } \\
\text { lipid } \\
\text { n }\end{array}$ & $\boldsymbol{n}$ & $\begin{array}{l}\text { p- } \\
\text { value }\end{array}$ \\
\hline Berolah raga & 46 & 33 & 79 & 0,048 \\
Tidak berolah & 23 & 35 & 58 & \\
raga & & & & \\
\hline Jumlah & 69 & 68 & 137 & \\
\hline
\end{tabular}

Hasil analisis menggambarkan bahwa responden yang melakukan aktfitas olahraga sebanyak $79(57,7 \%)$ dan yang tidak melakukan aktifitas olahraga sebanyak 58 (42,3\%). Dari hasil ini terlihat bahwa variabel aktifitas olahraga cukup tersebar merata ke dalam dua kategori dan lebih banyak responden dalam penelitian ini banyak yang melakukan aktifitas olahraga dan tidak beresiko terhadap hiperlipidemia.

Hasil analisis aktifitas olahraga responden dengan kejadian hiperlipidemia diperoleh bahwa ada sebanyak $33(41,8 \%)$ responden melakukan aktifitas olahraga dengan kejadian hiperlipidemia. Sedangkan responden yang tidak berolahraga sebanyak $35(60,3 \%)$ dengan kejadian hiperlipidemia. Hasil uji statistik diperoleh nilai $\mathrm{p}=0,048$ 
maka dapat disimpulkan bahwa ada hubungan yang signifikan aktifitas olahraga dengan kejadian hiperlipidemia. Dari hasil analisis diperoleh pula nilai $\mathrm{OR}=2,121$, artinya bahwa responden yang tidak berolahraga mempunyai resiko 2,121 kali untuk terjadi hiperlipidemia dibanding yang tidak berolahraga.

Hasil ini berbeda dengan hasil penelitian yang dilakukan oleh Supriyono (2008), yang mengatakan bahwa aktifitas olahraga tidak memiliki hubungan yang signifikan terhadap kejadian hiperlipidemia, bahwa aktifitas olahraga bukan merupakan faktor resiko untuk terjadinya hiperlipidemia.

Hasil ini menguatkan hasil penelitian yang dilakukan oleh Sukardi (2010) ${ }^{2}$,yang mengatakan bahwa terdapat hubungan yang signifikan aktifitas olahraga dengan kejadian hiperlipidemia

Hasil ini juga menguatkan hasil penelitian yang dilakukan oleh Kamso, Purwatyastuti, Juwita (2002) ${ }^{\mathbf{1 0}}$ bahwa aktifitas olahraga dengan kategori sedang dapat menurunkan kadar kolesterol total dalam darah, meningkatkan HDL-kolesterol. Selanjutnya hasil penelitian ini juga menguatkan hasil penetian yang lakukan oleh Edison (2010) bahwa aktifitas aerobik dapat menurunkan kadar kolesterol serta meningkatkan kadar HDL-kolesterol.

Manfaat olahraga yaitu meningkatkan kerja dan fungsi jantung, paru-paru dan pembuluh darah, yang ditandai dengan; denyut nadi istirahat menurun, isi sekuncup bertambah, kapasitas bertambah, penumpukan asam laktat berkurang, meningkatkan pembuluh darah kolateral, meningkatkan HDL-kolesterol dan mengurangi arterosklerosis.

\section{Indek Masa Tubuh responden dan terjadinya hiperlipidemia}

Tabel 6.

Distribusi responden menurut Indeks Masa Tubuh dan terjadinya hiperlipidemia.

\begin{tabular}{lllll}
\hline \multicolumn{1}{c}{$\begin{array}{l}\text { I M T } \\
\text { responden }\end{array}$} & $\begin{array}{l}\text { Hiperlipidemia } \\
\text { Tidak } \\
\text { hiper } \\
\text { lipid } \\
\text { n }\end{array}$ & $\begin{array}{l}\text { Hiper } \\
\text { lipid }\end{array}$ & $\mathbf{n}$ & p-value \\
\hline Berat & 35 & 1 & 54 & 0,011 \\
normal & & 9 & & \\
Berat & 34 & 4 & 83 & \\
lebih & & 9 & & \\
\hline \multicolumn{1}{c}{ Jumlah } & 69 & 6 & 137 & \\
& & 8 & & \\
\hline
\end{tabular}

Hasil analisis menggambarkan bahwa responden yang memiliki Indek Masa Tubuh berlebih sebanyak $83(60,6 \%)$ dan yang memiliki Indek Masa Tubuh normal (ideal) sebanyak 54 (39,4\%). Dari hasil ini terlihat bahwa variabel Indek Masa Tubuh tidak tersebar merata ke dalam dua kategori dan 
lebih banyak responden dalam penelitian ini masuk kategori IMT berlebih dan beresiko terhadap hiperlipidemia.

Hasil analisis antara Indek Masa Tubuh dengan kejadian hiperlipidemia diperoleh bahwa ada sebanyak 19 (35,2\%) responden Indek Masa Tubuh yang normal dengan kejadian hiperlipidemia. Sedangkan responden yang Indek Masa Tubuh berlebih sebanyak $49 \quad(59,0 \%)$ dengan kejadian hiperlipidemia. Hasil uji statistik diperoleh nilai $\mathrm{p}=0,011$ maka dapat disimpulkan bahwa ada hubungan yang signifikan Indek Masa Tubuh normal dengan kejadian hiperlipidemia. Dari hasil analisis diperoleh pula nilai $\mathrm{OR}=2,655$, artinya bahwa responden yang Indek Masa Tubuh berlebih mempunyai resiko 2,655 kali untuk terjadi hiperlipidemia dibanding yang Indek Masa Tubuh normal.

Hasil penelitian ini berbeda dengan hasil penelitian yang dilakukan oleh Supriyono (2008), yang mengatakan bahwa IMT berlebih tidak memiliki hubungan yang signifikan terhadap kejadian hiperlipidemia, dan bahwa IMT berlebih bukan merupakan faktor resiko untuk terjadinya hiperlipidemi ${ }^{8}$.

Hasil penelitian ini menguatkan hasil penetilian yang dilakukan oleh Kamso, Purwantyastuti, Juwita(2002) bahwa IMT

berlebih berhubungan secara signifikan terhadap kejadian Dislipidemia di Kota Padang ${ }^{10}$.

Obesitas menyebabkan hiperlipidemia, karena orang yang obesitas produksi kolesteron endogen per unit berat badan $20 \%$ lebih banyak dari yang tidak obese. Sedangkan untuk trigliserida walaupun mekanismenya tidak jelas akan tetapi pada orang yang mengkonsumsi makanan tinggi kalori, gula alkohol, dan karbohidrat sederhana kadar trigliseridnya akan mengalami peningkatan dan biasanya orang yang konsumsi makananya tinggi kalori adalah orang obese.

\section{Riwayat keturunan responden dan terjadinya hiperlipidemia}

Tabel 7.

Distribusi responden menurut riwayat penyakit keturunan dan terjadinya hiperlipidemia.

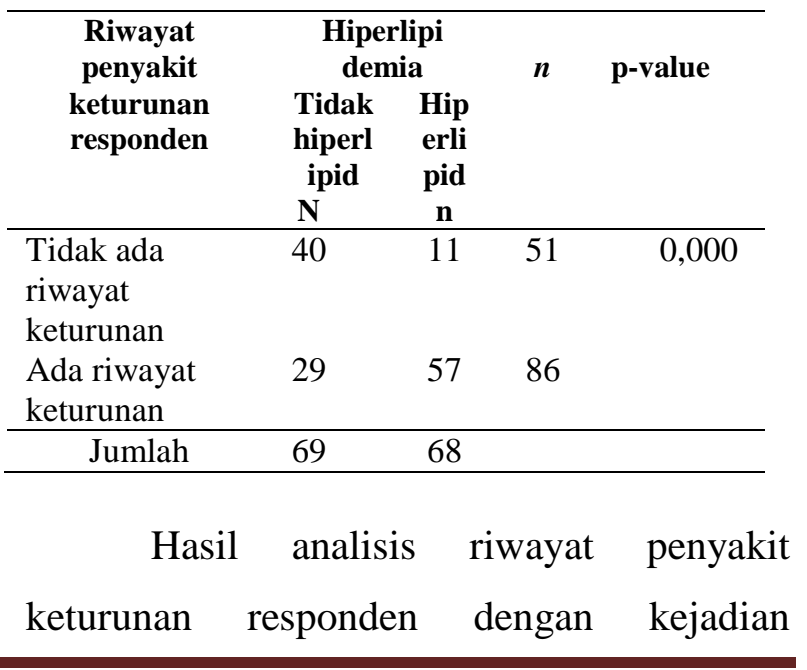


hiperlipidemia diperoleh bahwa ada sebanyak $11(21,6 \%)$ responden tidak ada riwayat penyakit keturunan dengan kejadian hiperlipidemia. Sedangkan responden yang ada riwayat penyakit keturunan sebanyak 57 $(66,3 \%)$ dengan kejadian hiperlipidemia. Hasil uji statistik diperoleh nilai $\mathrm{p}=0,000$ maka dapat disimpulkan bahwa ada hubungan yang signifikan riwayat keturunan dengan kejadian hiperlipidemia. Dari hasil analisis diperoleh pula nilai $\mathrm{OR}=7,147$, artinya bahwa responden yang memiliki riwayat penyakit keturunan mempunyai resiko 7,147 kali untuk terjadi hiperlipidemia dibanding yang tidak ada riwayat keturunan.

Hasil ini menguatkan hasil penelitian yang dilakukan oleh Sukardi (2010),yang mengatakan bahwa terdapat hubungan yang signifikan riwayat penyakit keturunan dengan kejadian hiperkolesterolemia. ${ }^{2}$ Tetapi Penelitian ini juga berbeda dengan yang dilakukan oleh Supriyono (2002) tidak terdapat hubungan yang signifikan kejadian PJK dengan riwayat orang tuanya menderita $\mathrm{PJK}^{8}$.

Riwayat penyakit keluarga disini dimaksudkan penyakit yang sangat erat kaitannya dengan hiperlipidemia yaitu hipertensi dan PJK. Adanya penyakit yang diderita juga oleh keturunannya menunjukan adanya pengaruh genetik. Pada hiperlipidemia gene yang mengatur sintesis protein enzim untuk metabolisme kolesterol, maupun sintesis apoprotein mengalami kelainan. Kadar kolesterol dan trigiliserida tinggi atau dikenal hiperlipidemia familial, yang diturunkan orang tua pada anaknya. Faktor genetik akan selalu berpose dan menghasilkan kolesterol tanpa henti. Misalkan ayah atau ibu kita memiliki penyakit kolesterol, kemungkinan besar kita tidak bisa lepas dari penyakit yang sama, sebab kita lahir dari hormon dan darah yang sama (Muhammad, 2009)

\section{Kebiasaan makan responden dan terjadinya hiperlipidemia}

Tabel 8.

Distribusi responden menurut kebiasaan makan dan terjadinya hiperlipidemia.

\begin{tabular}{rlccc}
\hline \multirow{2}{*}{$\begin{array}{c}\text { Hebiasaan } \\
\text { makan responden }\end{array}$} & $\begin{array}{l}\text { Hidak } \\
\text { hiper } \\
\text { lipid }\end{array}$ & $\begin{array}{c}\text { Hiper } \\
\text { lipid }\end{array}$ & $\boldsymbol{N}$ & $\begin{array}{c}\text { p- } \\
\text { value }\end{array}$ \\
& $\mathbf{n}$ & $\mathbf{n}$ & & \\
\hline Rendah lemak & 50 & 31 & 81 & 0,002 \\
Tinggi lemak & 19 & 37 & 56 & \\
\hline Jumlah & 69 & 68 & 137 & \\
\hline
\end{tabular}

Hasil analisis menggambarkan bahwa responden dengan kebiasaan konsumsi tinggi lemak sebanyak $56(40,9 \%)$ dan responden dengan konsumsi rendah lemak sebanyak 81 $(59,1 \%)$. Dari hasil ini terlihat bahwa 
variabel kebiasaan makan cukup tersebar merata ke dalam dua kategori namun lebih banyak responden yang tidak beresiko terhadap hiperlipidemia

Hasil analisis kebiasaan makan responden dengan kejadian hiperlipidemia diperoleh bahwa ada sebanyak 31 (38,3\%) responden kebiasaan makan rendah lemak dengan kejadian hiperlipidemia. Sedangkan responden dengan kebiasaan makan tinggi lemak sebanyak $37(66,1 \%)$ dengan kejadian hiperlipidemia. Hasil uji statistik diperoleh nilai $\mathrm{p}=0,002$ maka dapat disimpulkan bahwa ada hubungan yang signifikan kebiasaan makan tinggi lemak dengan kejadian hiperlipidemia. Dari hasil analisis diperoleh pula nilai $\mathrm{OR}=3,141$, artinya bahwa responden yang memiliki kebiasaan makan tinggi lemak mempunyai resiko 3,141 kali untuk terjadi hiperlipidemia dibanding yang memiliki kebiasaan makan rendah lemak.

Hasil penelitian ini senada dengan yang telah dilakukan oleh Kandau (2009) yang mengatakan bahwa kebiasaan makan tinggi lemak jenuh berhubungan signifikan dengan kejadian PJK di Sulawesi utara ${ }^{6}$

Kebiasaan makan yang salah yaitu protein hewani dikonsumsi lebih banyak dari protein nabati, kurang mengkonsumsi makanan tinggi serat serta hidrat arang dan lemak yang tinggi di samping dapat mengakibatkan overweight bahkan obesitas, dapat pula secara langsung meningkatkan kadar lemak darah.

Lemak jenuh sangat berbahaya bagi kesehatan, kelebihan lemak jenuh akan menyebabkan peningkatan kadar LDL kolesterol. Lemak jenuh bersumber dari makanan seperti; minyak kelapa, santan, minyak jagung, minyak kedelai dan lain-lain atau minyak yang telah mendapatkan pemanasan tinggi atau dipanaskan secara berulang-ulang (Muhammad, 2009) ${ }^{3}$

Menurut ornish dalam Muhammad (2009), mengurangi asupan makanan yang mengandung lemak hewani merupakan cara terbaik untuk menurunkan kolesterol, selanjutnya dalam penilitiannya ornish menyarankan pola makan vegetarian merupakan cara untuk melawan penyakit pembuluh darah seperti jantung. ${ }^{3}$

\section{SIMPULAN}

Tidak ada hubungan usia dengan kejadian hiperlipidemia.Tidak ada hubungan jenis kelamin dengan kejadian hiperlipidemia. Tidak ada hubungan jenjang pendidikan dengan kejadian hiperlipidemia. Ada hubungan aktifitas olahraga dengan kejadian hiperlipidemia. Ada hubungan riwayat 
penyakit keturunan dengan kejadian hiperlipidemia. Ada hubungan Indek Masa Tubuh dengan kejadian hiperlipidemia. Ada hubungan kebiasaan makan dengan kejadian hiperlipidemia.

\section{SARAN}

Kepada masyarakat yang memiliki kebiasaan makan tinggi lemak, kebiasaan tidak pernah melakukan aktifitas olah raga, memiliki Indek Masa Tubuh berlebih dan memiliki riwayat keturunan darah tinggi, PJK, hiperlipidemia, disarankan agar sering melakukan pemeriksaan darah secara rutin sehingga secara berkala dapat dipantau dan diketahui keadaan kimia darahnya. Karena mereka memiliki peluang lebih besar dibandingkan dengan seseorang yang tidak memiliki faktor resiko sebagaimana tersebut di atas.

\section{DAFTAR PUSTAKA}

1. Anis, Waspada ancaman penyakit tidak menular, Solusi pencegahan dari aspek perilaku dan lingkungan, PT Elex Media Komputindo, Jakarta, 2006.

2. Antonius Sukardi, Faktor-faktor yang berhubungan dengan kejadian hiperkolesterolemia pada pengunjung yang diperiksa kadar kolesterolnya di RSUD Abdul Moeloek Bandar Lampung 2010, Bandar Lampung, 2010
3. As'adi Muhammad, Waspadai Kolesterol Tinggi, Bukubiru, Yogyakarta, 2009

4. Dinas Kesehatan Propinsi Lampung, Profil Kesehatan propinsi Lampung Tahun 2009, Bandar Lampung, 2009

5. Departemen Kesehatan RI, survey Kesehatan Nasional 2001: Laporan Studi Mortalitas 2001: Pola penyakit penyebab kematian di Indonesia, Badan Penelitian dan Pengembangan Kesehatan, Jakarta, 2003

6. Grace D Kandau, Kebiasaan makan makanan etnik minahasa di propinsi Sulawesi utara, Jurnal Kesehatan Masyarakat, Vol 3, No 2, FK USR Manado, 2009

7. Mason W Freeman, MD dan Cristine Jungle, Kolesterol Rendah Jantung Sehat, PT BIP Kelompok Gramedia, Jakarta, 2005.

8. Mamat Supriyono, Faktor-faktor resiko yang berpengaruh terhadap kejadian penyakit jantung pada kelompok usia $\leq$ 45 tahun. Studi kasus di RSUP dan RS Telogorejo Semarang, UNDIP, 2008

9. Sarwono Waspadji, et.al, Pengkajian Status Gizi, Studi Epidemiologi, FKUI, Jakarta, 2003

10. Sujianto Kamso, Purwantyastuti, Ratna Juwita, Dislipidemia pada lansia lanjut usia di kota padang, Makara, Kesehatan, Vol 6 No 2, Jakarta, 2002

11. Susiana C Lantip R dan Thianti S, Kadar melondiadehid (MDA) penderita penyakit jantung koroner di RSUP Dr. Sarjito Yogyakarta, Mandala of Health, a Sciantific Journal, vol 2, 2006. 
